\title{
Institutional and Educational Transformation of Pesantren in Social Capital Perspective: A Phenomenological Study at Pesantren of Miftahul Ulum, Suren, Jember
}

\author{
Saihan \\ Universitas Islam Negeri Kiai Haji Achmad SiddiqJember \\ Email: saihanuinjbr@gmail.com \\ Umiarso \\ University of Muhammadiyah Malang \\ Email: umiarso@umm.ac.id
}

\begin{abstract}
:
This research focused on the development of pesantren, especially in the institutional and educational aspects using a social capital perspective. Pesantren used as a research site was Pesantren of Miftahul Ulum, Suren, Jember. To delve into the focus of this research, the researchers, thus, tried to understand and interpret the development of pesantren from social capital perspective. To achieve these objectives, this research was conducted by using a qualitative approach with the type of phenomenology using a single site design. The data collection technique used was participant observation so that researchers could participate in every Islamic boarding school's institutional and educational programs. This research results showed that: First, social capital contributing to pesantren carries out institutional development and change from an isolating-traditionalist paradigmatic to a modernist-synthetic one. These changes can be seen from the openness of pesantren system to modernization and social change in society; Second, social capital also encourages the development and education change from a dichotomous to a non-dichotomous pattern. This pattern manifests itself in the education system; it initially only teaches religious sciences and was oriented towards God (theocentric) but it is developed into the teaching of religious and general sciences, and is oriented toward spiritual-humanist values; and third, social capital from theological values has also become a potential for pesantren as
\end{abstract}


spiritual patrons and the vanguard of values and morality for the surrounding community.

Keywords: Development of pesantren, Institutional and educational aspects, and Social capital

\section{A. Introduction}

This research focused on the development of pesantren, especially in the institutional and educational aspects from social capital perspective. This study is very important to do to understand and interpret the pattern of pesantren development based on social perspective. In fact, the development of pesantren has a unique and interesting dimension to be studied thoroughly and comprehensively. It is like Thoyib's research which looked at the development of pesantren from the aspect of Kiai leadership;(Thoyib, 2018, p. 79-99) Solichin's research that described the authority of Kiai in developing pesantren;(Solichin, 2018, p. 88-100) or Irawan's research that tried to examine the roots of Islamic ethics which are compounded with local culture so those researches make pesantren continues to exist.(Aguk Irawan M.N, 2018, p. 13) However, various emerging researches still focus on examining the dimensions of pesantren development from the point of view of the internality of pesantren such as institutional management, the theological-philosophical value of its education, or its intellectual genealogical basis. Therefore, the development of pesantren needs to be investigated further from a sociological point of view in order to see the other potentials of pesantren.

Based on this framework, we will be able to see the flow and pattern of institutional and educational development of the pesantren studied from a social basis. One of them is through pesantren social capital. With this potential, the pesantren relates itself to the community. This relationship does not appear immediately but it is from the interaction between pesantren and community consciously. Therefore, Bourdieu emphasizes that social capital is from self-awareness to interact and create strong relationships that are both shortterm and long-term.(Pierre Bourdieu, 1986, p. 257) In fact, as Gelderblom's research, it is concluded that it will also form a cooperative or competitive attitude.(Derik Gelderblom, 2018, p. 1-16) It is natural that the development of pesantren is strongly tied to the trust of the community and the social networks that have been created. On the one hand, the pesantren itself has contributed to social empowerment. Such as revealed in Widayati's research that pesantren are able to empower the community;(Widayati, 2020, p. 51-79) or research by Apud, et al. about the role of the Kiai in developing the nationalism values.(Apud et al., 2020, p. 153-164) 
Even so with Pesantren of Miftahul Ulum, Suren, Jember hereinafter will be written PMUS- which continues to experience development starting from its learning system: education and institutions. They orientate the modernization of this pesantren so that it can meet the needs of the community while maintaining its strong roots in traditional Islamic education. This is believed by Lukens-Bull that pesantren will contribute to the future of Indonesian nation as a pluralistic, peaceful, and democratic society.(Lukens-Bull, 2019, p. 2948) Regardless of that belief, on the one hand, the community accepts this construction in the form of a participatory attitude in developing pesantren. The relationship between pesantren and community fosters a pattern of interrelation in terms of cooperation in the form of beneficial attitudes and actions. According to Coleman, the interactions that occur will emerge to norms, values in action, knowledge systems, and also relationships between individuals or communities.(Coleman, 1988, p. 95-120)

Therefore, the emerging social capital is able to encourage a massive movement for the development of pesantren. Pesantren development and change are realized critically by remaining on the central axis where an Islamic religious education institution takes place. This function is as a form of ulama' (tafaqquh fi al-din) and spreads the religion of Islam (da'wah islamiyyah) when pesantren development journey is initially seen as the development journey that only teaches religious sciences. However, from the 1990s, PMUS has been colored by general and even vocational sciences (automotive, computer, and culinary arts). The pace of development of PMUS itself can be classified into three phases, namely: first, the pioneering phase from 1952 to 1980; second, the development phase from 1980 to 2018; and third, the phase of development and change starting in 2018 until now. These phases are integrated with efforts to maintain and develop public trust and expand social networks (and pesantren sciences). In this context, it can be said that social capital can be the basis for pesantren's institutional and educational development.

Based on the research argument description, this research focused on the construction of institutional and educational development of pesantren from the social capital point of view. This focus raised the research question 'how is the construction of social capital as the basis for institutional and educational development at PMUS?'. This question was then answered empirically using a qualitative approach so that researchers can understand and interpret the reality of pesantren development. Whereas, the type of research used was the phenomenological study so that researchers can be thoroughly and comprehensively understanding and interpreting this reality from the point of view of social capital and the 
Saihan, Umiarso

implications it raises. For data collection techniques, researchers used the participant observation techniques to make them easier to participate in every pesantren activity.

\section{B. Discussion}

\section{Social Capital in PMUS}

In pesantren or in various other institutions, social capital has been the focus of intense debate since the early 1990s-early 20th century.(Lindsay Paterson, 2000, p. 5; Robert D. Putnam, 2000, p. 19) The basic idea is society; in this case pesantren, can use their network with others as a potential resource. The use of this network is not necessarily able to frame the polarization of achieving the pesantren goals without a social structure that regulates it. Therefore, Coleman, when analyzing social capital in the economic field, emphasizes the primacy of norms for economic growth and development.(Douglas D. Heckathorn, 2003, p. 280) It means that the idea of the substance of pesantren social capital needs to be adjusted to the norms that exist in society in order to get maximum benefits. Moreover, factually, social capital can be a strength for pesantren so that they can build a society in accordance with the ideals and characteristics of their religious locality. PMUS carries out social transformation in the midst of society based on the potential (strength) of its social capital. As stated by one PMUS Ustadz that:

"This pesantren has changed from time to time based on the strength that is within itself. The community puts a high trust in pesantren so that the community with their sincerity helps pesantren to raise itself. Vice versa, pesantren also positively affect the community by shaping their morals and akhlaq through their education".

Although, social capital has broad benefits, experts still have different views. As revealed by Putnam, who has different views on two timescales of research, namely: during the research on Italian political traditions and research on American society. Even, Bourdieu interprets social capital differently when he examines European society with an emphasis on social class and social injustice. This happens because social capital is often associated with other aspects that are sometimes counterproductive to social capital itself. Reasonably, Lin, et al., stated that without a clear conceptualization, social capital will quickly become a term used for everything that has a "social" term.(Nan Lin, 2001, p. 57) This diversity, indeed, needs to be limited in pesantren.

Social capital in the community is often associated with other aspects such as stability, integration, trust, solidarity, and tolerance. It is, in turn, used to explain differential economic growth or even crime rates between regions.(Turner, 2006, p. 413) Therefore, it is understood 
as an entity that refers to the collective interests of social networks which are built based on mutual trust.(Richard T. Schaefer, 2018, p. 13) In this context, it can defined as a characteristic that exists in social organizations, such as trust, norms, and networks that increase the efficiency of society by facilitating coordinated actions.(John Field, 2008a, p. 4) Social capital has three forming values: a). Trust that needs to be nurtured and grown; b). Applicable social norms need to be adhered together, and c). Social networks need to be developed and strengthened.

The development of PMUS itself cannot be separated from these three aspects because it was from theological (religious) roots. Thus, social capital in PMUS has underpinned the development and social stability that characterizes the realization of the institutional and educational goals of the pesantren. Putnam has admitted that the features of social life, such as social networks, norms, and beliefs, can all be used to act together to achieve common goals more effectively.(John Field, 2008b, p. 35) It means that PMUS has a great opportunity to carry out institutional and educational transformation as well as to create a unified orientation based on religious values. One of Ustadz stated that:

"Pesantren network is extensive, covering the scientific network obtained by Kiai dan Lora -biological descendants or sons of Kiai, researchers. Or also the institutional network between Pesantren of Miftahul Ulum and other pesantren throughout Jember district of East Java province; even with government or private agencies. All of them have purpose to strengthen the students and the community religion".

From the social construction of pesantren, PMUS has an integrative orientation and goals: the educational dimension, which is closely related to the religious dimension. Kutsiyah's research proved that social capital actually triggers the existence of students whose a strong scientific dimension and growth of an entrepreneurial spirit.(Kutsiyah, 2020, p. 57-94) Other sociologists, such as Hooghe \& Stolle consider social capital to be a very urgent resource for society and communities existence.(Hooghe \& Stolle, 2003, p. 2)

Putnam proved in his research that in areas of good local government functions and a prosperous economy, community activities are created by an atmosphere of cooperation, good social networks, established political relations, and high participation. Behind this phenomenon radiates an ethos of mutual trust between its citizens.(Robert D. Putnam, 1993, p. 6-7) Likewise, in PMUS, social capital configured intrust creates a pesantren institutional arrangement following a shared ideal (that is, between internal groups (caregivers or pesantren administrators) and the community (external)). This condition impacts the development of 
Saihan, Umiarso

the pesantren education system that can be carried out independently using a collectivecollegial and familial work pattern. The Ustadz of PMUS himself stated that:

"The cooperation between pesantren and the community is solid because trust has been established by strengthening each other. However, pesantren provide facilities in the form of spiritual strengthening through education. Therefore, the community leaders always hold deliberations to find solutions to pesantren or community problems. Our collaboration is also very harmonious".

In PMUS, social capital plays an important role in connecting each pesantren's individual within the framework of a unified orientation of institutional and educational transformation. In this position, Bourdieu believes that social capital is social relations capital that will provide something that is able to support when it is needed: a very valuable and desirable capital, it is often needed if one wants to attract clients in socially important positions.(Foas \& Knobl, 2011, p. 18) Therefore, social capital is a very useful resource and it is available to the actors through their social relationships.(John Field, 2008c, p. 15) Reasonably that PMUS emphasizes the functional differences between social capital and human capital; although the two are interrelated in the social activities of the pesantren. For PMUS, human capital is positioned as a subject whose interactions are filled with belief values based on Islamic religious norms. Meanwhile, social capital is used as the basis for the institutional and educational development of PMUS in the form of mutual trust; norms; network; reciprocity; and focus on achieving the pesantren goals.

These values encourage PMUS to move dynamically in managing its institution and existing education system. This reality seems to prove Coleman's thesis; in which he stated that groups which have members demonstrate credibility and give one another broad trust will be able to do things better than comparable groups that lack the credibility and trust. (Coleman, 2011, p. 421) It is clear that social capital for PMUS is developed massively centered on the superiority of pesantren education. For an example is the PMUS education system that runs following the pace of development of science and technology without breaking away from the theological and philosophical values of Islamic institutions. Therefore, the social capital in PMUS is used to open up barriers to institutional and educational transformation stagnation. Lin has admitted that social capital is a resource that is able to manage and generate various potentials and structures in order to take advantage of opportunities; understand hierarchical structures, social networks, and actors, as well as macro-micro (hierarchical-individual) connecting bridges, so that it can be an investment to realize common goals.(Nan Lin, 2008, p. 51) 
Interestingly, in PMUS, mutual trust is essential in carrying out the institutional transformation, developing and improving pesantren's social welfare. However, this condition does not necessarily appear and become part of the social life of the pesantren without mutual respect and honesty in the PMUS community itself. Researchers see that mutual trust encourages PMUS human resources to work together to bring up activities in more effective collective actions. Mutual trust arises from social norms based on religious values, which internalize in each PMUS component. In Futaqi's research, social trust is an external capital that appears with the bridging type between pesantren and community.(Futaqi, 2020, p. 6478) Moreover, this is also reinforced by the statement of one of the teacher councils.

"The potential that exists in this pesantren is seen as a positive potential by the community. Indeed, the name of pesantren cannot be separated from Islamic religious values, so this potential becomes the internal potential of pesantren which has superiority. Moreover, aligning pesantren behavior with religious values encourages pesantren to foster public trust and guide the community to have a solid religious foundation. At the same time, internality itself is to develop existing education".

On the basis of trust urgency, PMUS in its social capital structure positions trust-in addition to social norms and social networks- as the main locus. It is not only about "pesantren subject" personally, but also the majority of pesantren's human resources. Moreover, PMUS collective belief has a broader locus, namely trust that arises from Islamic theological values. As it is the case of fostering harmonious social interaction which is similar to maintain the values of brotherhood in the faith -ukhuwah islamiyyah. It is a fact that individual actors do things for the common good not because they know other individuals, but because they believe that their own actions will be "rewarded" through the development of positive communal relationships.(Kenneth Newton, 1999, p. 8) Trust for PMUS is a symbol of expectations for order, honesty, and cooperative behavior that emerges from pesantren and is based on shared norms. These norms may contain questions ranging from "theological values" such as the nature of God or justice.

The positive implications of theological values at PMUS have in common with Weber's fundamental study, namely "The Protestant Ethic and the Spirit of Capitalism." He conducted a research from a sociological perspective by looking at social institutions (religion) as the spirit of mobility for developing capitalism in Germany. It is common for him to put forward the thesis that there is a strong correlation between the Protestant ethic and the development of capitalism; although Giddens judged that this research was written with polemical intent; The Protestant Ethic was written with polemical intent-.(Anthony Giddens, 
2001, p. xviii) However, Weber's thesis was proven when the beliefs that emerged at PMUS base on Islamic theology or Islamic teachings, so that it could encourage the spirit of transforming pesantren institutions and education. Even for modern pesantren, trust occupies a critical position like Seligman, who states that modern society emphasizes consensus based on interconnected networks of trust, including their "legitimacy" founded on the "trust" of authorities and governments generalizations.(Adam Seligman, 1997, p. 14)

On the one hand, the PMUS social network accelerates the pace of pesantren's institutional and educational transformation. It can be likened to a model of relations between pesantren subjects who are connected by sympathy and obligation as well as by values and norms of exchange. Thus, PMUS is organized by subjects (individuals) who interact together everyday with an orientation towards one underlying interest and motivation. One example is seen from educative actions, the PMUS social network is a community that shares values and informal theological-based norms to interact with the aim of gaining knowledge and "blessing". From this framework, social capital in PMUS is not only useful for pesantren transformation but it also has use-value for the development of pesantren subject personality.

\section{Roles of PMUS Based on Social Capital}

Pesantren is an Islamic educational institution that is believed to have existed since the Hindu-Buddhist period(Eka Srimulyani, 2012, p. 16; Robert W. Hefner, 2009, p. 5) and is also used as an Indonesian heirloom.(Budhy Munawar Rachman, 2006, p. 2668) It tends to be perceived as a religious school that is boarding and run communally (groups)(Greg Barton, 2002, p. 37) in the countryside.(Colin Brown, 2003a, p. xvii; Umar, 2014, p. 9) Pesantren -like PMUS, positions itself as a da'wah institution or a traditional learning center for Muslims(Ahmad Syafii Maarif, 2015, p. 245; Bruinessen, 2012, p. 85) by emphasizing the importance of religious morality (Islam).(Qomar, 2012, p. 68) This position places PMUS as a center for producing values and traditions that are used as references for public behavior.(Abdul Munir Mulkhan, 2011, p. xiv) This is what places PMUS as a patron that builds the noble behavior of the community around pesantren. On one hand, it also brought up efforts to maintain identity, preserve tradition, and perpetuate the hierarchy of social institutions in pesantren community itself, including to carry out the purification of religion and religious understanding performed by reformers in rural areas such as in East Java.(Ahmad Mansur Suryanegara, 1998, p. 130; Azra, 1999, pp. 35-36; Colin Brown, 2003b, p. 116)

These characteristics are firmly attached to PMUS to interact with themselves to serve their religious education needs. Even PMUS stands at the forefront to filter out values and 
norms that are not under Islamic religious doctrine. Therefore, PMUS is a symbol of filtering based on Islamic theological values; and it is also a symbol that connects the rural world with the outside world.(Darwis, 2010, p. 233; Martin Van Bruinessen, 1999, p. 238) Naturally, PMUS claim to be a social institution in the form of an Islamic educational institution -with a set of supporting elements such as Kiai, mosques, santri, dormitories, and Kitab Kuning. However, it is also considered as a preserver of Islamic culture in surrounding community social life. Therefore, research by Marzuki et al. concluded that many pesantren, through their education system, can prevent the spread of religious radicalism in society.(Marzuki et al., 2020, p. 12-25)

Interestingly, at the beginning of its development, PMUS was not standardized and organized systematically and proportionally. However, it developed institutions and education through an isolative-traditionalist paradigmatic system (a pattern of apathy towards a system that smells Western and emphasizes religious knowledge) to a modernist synthesis (a pattern of bringing together pesantren education with the West to emerge a modern education system (madrasah)). Raihani found that pesantren are very dynamic in developing themselves into modern Islamic institutions; (Raihani, 2012, p. 585-605) or the adaptive attitude of pesantren in a changing context.(M. Falikul Isbah, 2020, p. 65-106) This condition means that PMUS is developing, driven by the dynamics of managers supported by the power of social networks. The power of social networks includes PMUS's open attitude towards social change, which ultimately requires PMUS to take new and better aspects and maintain the relevant old ones. Of course, there is a dialogical effort between this new aspect and the Islamic theological value, the standard of its ideals.

Therefore, values and norms that arise from PMUS have perennial power in society. For example, the concept of multicultural variation or moderation has grown from pesantren, as Hoon said with religious multiculturalism.(Hoon, 2017, p. 476-493) PMUS itself, when carrying out institutional and educational transformations, focused on building a social order with religious nuances; this is what Suradi in his research termed ideological goals.(Suradi, 2018, p. 27-38) So based on ideological commitment (religious beliefs), moving the subject of PMUS has a strong bond in the form of mutually agreed-upon values and norms. This situation triggers the vital trust of PMUS subjects or even the community towards pesantren.

Although PMUS was first establishing with an isolative-traditionalist style moving to a modernist synthesis, it still includes and maintains religious books as their scientific locus. Naturally, people believe that PMUS is still a transmitter of Islamic normative values to the current generation. This shift -from its institutions to its learning system- the main 
characteristics of PMUS as an Islamic religious education institution are still maintained and synergized with the social changes that occur. People quickly see the implementation of humanist and inclusive religious education by balancing the development of rational-empirical scholarship. Therefore, PMUS can be an ideal pesantren; according to the conclusion of Zulfa's research, the ideal pesantren upholds inclusive religious education and balances the development of reason and revelation.(Umi Zulfa, 2018, p. 225-251)

The strong theological values and Islamic religious norms at PMUS make the issue of adopting Western science and technology less debatable. However, PMUS followed and adopted it by providing contents of Islamic spirituality. It seems that what this pesantren has done is to refute Theodorson's view that people who accept Western technology will inevitably imitate the pattern of Western society that sends the technology.(Robert H. Lauer, 1993a, p. 19) The PMUS collectivity in the form of family values based on Islamic principles has also become a force for the transformation of pesantren without having to imitate Western patterns. The local community believes that they actually have the original cultural treasures (ie: pesantren) that can be positioned as the vanguard of social transformation.

PMUS itself tries to be different from Pesantren in general which tend to be in the ivory tower, elitist, far from social reality that full of social problems (such as poverty, dehumanization, and moral decadence) or paradigmatic problems (ie: wanting to build a theocentric-oriented scientific tradition). These problems lead to the occurrence of gaps, alienation, and differentiation between Pesantren and the modern world. PMUS awareness of social reality creates a basic framework for the education system that balances the dimensions of aqliyah and qalbiyah; between profanistic reasoning rational-empirical and transcendental reasoning intuitive-revelation. When researchers classify education at PMUS, it is found that there are six dimensions of education, namely: physical education (al-ahdaf al-jismiyah), spiritual education (al-ahdaf al-ruhaniyah), intellectual education (al-ahdaf al-aqliyah), social education (al-ahdaf al-ijtimaiyah), moral education (akhlaq), and aesthetic education (beauty).

PMUS is aware of the condition of the output (graduates) of pesantren that sometimes cannot compete with graduates of general education institution in the professional work world. PMUS considers that it has the responsibility to people, thus the transformation of pesantren education takes a place from a dichotomous system to a non-dichotomous education pattern (ie: education that is oriented towards spiritualistic-humanist values). Consequently, it tries to form pesantren outputs that are able to compete through various vocational trainings and also reconstruct the internality of education system from theocentric 
to theoanthropocentric patterns. According to Ubaedullah, et al, this form of PMUS service to the community foster student loyalty to pesantren.(Ubaedullah et al., 2019, p. 254-260)

\section{PMUS Macro Functionalization of Social Capital}

This PMUS gait has strengthened the dimensions of social networking and trust in internality (subjects of pesantren) and externalities (stakeholders and society). On one hand, through reflective thinking, PMUS opens space for development and improvement of people's living standards by understanding the problems rationally. The PMUS transformation opened a system of social stratification in society which was originally very closed to vertical mobility. Currently the top social class is filled with people who were originally in the lower-class social stratification. This condition has implications for the transition process from -or the social transformation of- a feudal-structured society into a rational-bureaucratic one. Consequently, the social community around PMUS prioritizes the rules that have been recognized and adhered to by the community and legalized by the state. The authority that the community obeys arises from formal legality based on the legal system; Weber called this pattern with the term rational-legal authority.(Ritzer, 2001, p. 43; Ritzer \& Goodman, 2011, p. 37) Ustadz of PMUS explain this condition:

"The community feels this pesantren existence. In the early days of establishing this pesantren, the community was still very feudal, and their society were as farmers. In 1980s, this pesantren emphasized the institutionalization of pesantren to be more open and receptive to new things. Because the community received their education at this pesantren, it also began to change traditional thinking to very rational thinking especially those related to the rules that apply in society".

In this realm, the state is positioned as the authority holder whose function is to support, distribute, and regulate the community work. The reality of this functionality, according to Halevy \& Etzioni, is a framework for the transition of society from traditional to modern.(Etzioni-Halevy \& Etzioni, 1974, p. 177) PMUS through its institutions encourages the creation of social order in accordance with Islamic religious values as a result of their interpretation. While the internalization is carried out through an indoctrinative pattern in PMUS education, so that the community feels they have a religious patron who flows values and norms. In fact, pesantren can inspire people, as revealed by Anam et al. because they are friendly, uphold human rights, are democratic, pluralist and tolerant of religion.(Saeful Anam, 2019, p. 815-834)

Actually, between PMUS and the community, there is a mutually beneficial dialectical relationship. Various ideas from PMUS were from Islamic doctrine and the thought of the salaf 
scholars try to accompany and form social organizations. However, it still relies on a complex network of interpersonal ties to bind community members collectively. This situation is a social network (between PMUS and the community) that has value as social contact and has an influence on individual and group productivity.(Julia Hauberer, 2011, p. 53) Reasonably, PMUS can channel its ideas supported by a strong social network, thus its values and norms can be diffused into the community. However, he does not necessarily become a part "forced" following the normative values that PMUS believes in. But there is a historical dialectical process with social reality (society) so that it can space and time and become part of the unity of human history. Descartes or Kant views the dialectical process in society as an epistemological construction.(Bryan Magee, 2005, p. 190-191) In general, in Javanese society, as well as in PTMUS, the emerge of these ideas came from the Kiai who colors the flow of social transformation.(Fauzi, 2012, p. 125-144) One of teachers told the researcher:

"Rational thinking, especially those rooted in the religious dimension of Islam, is the result of the kiai's thoughts. Very passionate in the condition of the community around the pesantren as if the thought is the result of "prediction" of the future. However, Kiai through pesantren already has trust and networks so that these ideas can be applied in society".

This contribution cannot be realized without the active role of PMUS through its social and institutional functions. And according to Erniati's research, this role is a macro challenge to work on the institutional triumvirate.(Erniati, 2017, p. 37-58) Therefore, PMUS tries to identify, continue, and contribute to the community. Berger \& Luckmann analyzed that awareness is always intentional; it will continue to focus on the object. We cannot understand what is considered as the substratum (base) of that awareness, except the awareness of something.(Berger \& Luckmann, 1990, p. 29) It is undeniable that the PMUS ideas ultimately lead to a social order that follows the theological values they profess. However, rational collaboration in planning and action between PMUS and the community is impossible without a distribution process. Berger \& Luckmann called this process as internalization.

Benne in this context emphasizes the ability of innovators to find methodologies that can develop an understanding of the rational factors of the group members and leaders.(Kenneth D. Benne, 2008, p. 79) It means that when PMUS is positioned as an innovator, it needs to frame theological values and religious norms with a methodological framework. It should follow the social reality in society so that PMUS's free action that is voluntarily based on spirituality produces an ideal social reality (structure). If it is viewed empirically, the efforts made by PMUS are indeed able to encourage people's lives in a better direction. The foundation of values that PMUS uses is the spirit of jihad towards sincerity in 
worship; indeed, the concept of jihad taught by pesantren does not contain elements of radicalism.(Tafsir \& Aziz, 2019, p. 37-52)

All aspects carried out by PMUS are formed in social resources, which are tied to the dimension of trust. This dimension is very configurative in PMUS and easily seen by the surrounding community so that when PMUS conveys and implements its ideas, the community is straightforward to accept. It is natural that this variant significantly affects the polarity of PMUS mobilization to create a society that follows its prophetic vision. The ability in PMUS is maximally utilizing to bring its ideas to the world of practice. Ustadz of PMUS stated:

"This pesantren tries to take care of the religious treasures that exist in pesantren, such as tauhid, moderation, sincerity, tawaddu' to Islamic belief, or other things. Of course, these treasures need to be the basis of people's lives because the community needs to be nurtured and empowered by a father figure or religious figure".

Thus, PMUS positions itself as a patron of the social realities of the surrounding community. This reality can confirm Holmes' thesis that Islamic institutions with high social capital will distinguish himself from others.(Mary Holmes, 2010, p. 111) Even Ritzer argues that social capital consists of valuable social relationships; (George Ritzer, 2011, p. 533) trust, and interpersonal connections (network)(Marc Hooghe \& Dietlind Stolle, 2003, p. 2) so social capital for PMUS can be used proportionally. Therefore, Coleman states that social capital can be a normative trait in relationships (interpersonal connections) beneficial for cognitive and social development.(Coleman, 1988b, p. 43; James S. Coleman, 2011, p. 415)

Thus, the PMUS social network and trust owned can break through the backwardness of the surrounding community, even the subject of PMUS itself strengthens institutions and education to be more contributive to social transformation. Bourdieu's thesis in this context is authentic if someone who has much social capital is the first person to go to a new position.(Cheryl Hardy, 2008, p. 135) With these two dimensions, PMUS can be encouraged to transform its institutions and education from traditional to modern management, from the theocentric scientific tradition to theoanthropocentric pattern. The transformation at PMUS emerges from the creative role of the community's contribution that encourages the paradigm transition of integrative pesantren education. So, according to Saefudin's research findings, the $21^{\text {st }}$ century is a momentum for the integration of religious sciences and general sciences.(Saefudin, 2021, p. 1-23) One Ustadz explained:

"The community voluntarily helps pesantren carry out the development and changes. The community helps pesantren by contributing ideas and attitudes to support 
various programs of pesantren education system even from the energy and costs for the construction of this pesantren. I see this being done because people believe that this pesantren will provide comfort, peace, and a way out whenever there is a problem".

For this reason, in terms of pesantren transformation that involves the role of the community, PMUS tries to be selective in their thoughts and creativity. Because the perennial values of pesantren (such as theological and philosophical spiritual values) need to be firmly tied when there is institutional and educational transformation. When the social structure of Islamic institutions undergoes a transformation, it has implications for changes in the values, attitudes, and behavior of the community towards PMUS. Lauer admits that if the social structure in which individuals think and act is transformed, then values, attitudes, and behavior will also change.(Robert H. Lauer, 1993b, p. 481) Hence, the objectification ability -using the terms by Berger \& Luckmann- appears in PMUS. One example is that through social capital, it manifests itself in various social creations of society, both as producers and supplements to elements of social structure. People finally see that PMUS is very sensitive to social problems as a form of prophetic sensitivity with its institutional and institutional potential.

This phenomenon can be said to be a social transformation movement carried out by PMUS by encouraging people to the spirit of unity. Ruch believes that if this unity fosters family values supported by the principle of trust, it will become the basis of professional relationships.(Gillian Ruch, 2010, p. 23) Conversely, the transformation of PMUS driven by social capital can influence on the wider institutional and educational dimensions. If it is in society, according to Mouzeliz, it will have a direct effect on other changes such as economics and politics.(Nicos Mouzelis, 2005, p. 42) The PMUS transformation has implications for social transformation driven by the spirit that emerges from the womb of informal values and norms that are shared among pesantren subjects (or society) that enable cooperation among them. This is what sociologists like Huysman \& Wulf define as social capital.(Huysman \& Wulf, 2004, p. 1)

With social capital, PMUS has the ability to work together solidly to realize the prophetic goals of Islamic institutions. Therefore, at certain times, social capital can facilitate the degree of innovation and adaptability of PMUS to carry out institutional and educational transformations. It is as Muhith \& Umiarso's research which found that social capital (trust and social networks) is used to develop pesantren in the Madurese community.(El-Rumi \& Muhith, 2020, p. 119-136) Reasonably for people to judge that social capital is a fundamental asset capable of generating the future.(Elinor Ostrom \& T.K. Ahn, 2009, p. 19) Because with 
social capital, the institutional and educational development of PMUS is realized and social order can be built constructively.

\section{Conclusion}

Through social capital, PMUS can develop itself to be more expansive and accommodative for social transformation. Therefore, PMUS is able to continue to develop its institutions and education so that at this time, it appears to be a synthetic-modernist Islamic educational institution. The education system is implemented using the paradigm of integration between the religious sciences and the general sciences; in a theoanthropocentric pattern. PMUS itself functions effectively with social capital through a pattern of connectedness between the dimensions of the value of mutual trust; norms; network; and reciprocity. All of these dimensions are oriented to focus the PMUS subjects on the realization of pesantren prophetic goals.

Even, social capital can be used for the benefit of social transformation through the PMUS education system. In the context of social transformation, the existence of PMUS social capital is a guarantee of strong social relations between pesantren and community. Therefore, social capital is an institutional resource for pesantren which is seen as an investment to obtain new resources; in which social capital emphasizes more on the potential of Islamic institutions and the pattern of relationships between pesantren subjects personally -or between pesantren community and the general community. Thus, the various dimensions of social capital (ie: trust, social networks, values, and norms) that are from pesantren subjects are indeed the ideal potential for pesantren sustainability.

\section{References}

Abdul Munir Mulkhan. (2011). Membangun Tradisi Ilmu Pesantren. In Pesantren di Tengah Arus Mutu Pendidikan: Menjawab Problematika Kontemporer Manajemen Mutu Pesantren (p. xiv). RaSAIL.

Adam Seligman. (1997). The Problem of Trust. Princeton University Press.

Aguk Irawan M.N. (2018). Akar Sejarah Etika Pesantren di Nusantara: dari Era Sriwijaya sampai Pesantren Tebu Ireng dan Ploso. Pustaka Iiman.

Ahmad Mansur Suryanegara. (1998). Menemukan Sejarah: Wacana Pergerakan Islam di Indonesia. Mizan.

Ahmad Syafii Maarif. (2015). Islam dalam Bingkai Keindonesiaan dan Kemanusiaan: Sebuah Refleksi Sejarah. Mizan. 
Anthony Giddens. (2001). Introduction. In M. Weber (Ed.), The Protestant Ethic and the Spirit of Capitalisme (p. xviii). Routledge.

Apud, A., Bin Hj Adam, H. S., \& Irawan, F. (2020). Kyai Leadership in Internalizing Nationalism Values at Pesantren. Jurnal Pendidikan Islam, 6(2), 153-164.

Azra, A. (1999). Renaisans Islam Asia Tenggara: Sejarah Wacana \& Kekuasaan. Remaja Rosdakarya.

Berger, P. L., \& Luckmann, T. (1990). Tafsir Sosial Atas Kenyataan: Risalah tentang Sosiologi Pengetahuan (Hasan Basri (ed.)). LP3ES.

Bruinessen, M. van. (2012). Kitab Kuning, Pesantren dan Tarekat. Gading Publishing.

Bryan Magee. (2005). Memoar Seorang Filosof: Pengembaraan di Belantara Filsafat (Eko Prastyo (ed.)). Mizan.

Budhy Munawar Rachman. (2006). Ensiklopedi Nurcholish Madjid: Pemikiran Islam di Kanvas Peradaban (Budhy Munawar Rachman (ed.); 3rd ed.). Mizan.

Cheryl Hardy. (2008). Hysteresis. In Michael Grenfell (Ed.), Pierre Bourdieu: Key Concepts (p. 135). Acumen Publishing Limited.

Coleman, J. S. (1988a). Social capital in the creation of human capital. American Journal of Sociology, 94(supplement), 95-120. https://doi.org/10.1086/228943

Coleman, J. S. (1988b). Social Capital in the Creation of Human Capital. Knowledge and Social Capital, 94(Supplement), 95-120.

Coleman, J. S. (2011). Dasar-Dasar Teori Sosial: Foundations of Social Theory (I. Mutaqien (ed.)). Nusa Media.

Colin Brown. (2003a). A Short History of Indonesia: The Unlikely Nation? (1st ed.). Allen \& Unwin.

Colin Brown. (2003b). A Short History of Indonesia: The Unlikely Nation? Allen \& Unwin.

Darwis, D. (2010). Dinamika Pendidikan Islam: Sejarah, Ragam, dan Kelembagaan. RaSAIL.

Derik Gelderblom. (2018). The Limits to Bridging Social Capital: Power, Social Context and the Theory of Robert Putnam. The Sociological Review, 66(6), 1-16. https://doi.org/https://doi.org/10.1177\%2F0038026118765360

Douglas D. Heckathorn. (2003). Sociological Rational Choice. In George Ritzer \& Barry Smart (Ed.), Handbook of Social Theory (p. 280). SAGE Publications.

Eka Srimulyani. (2012). Women from Traditional Islamic Educational Institutions in Indonesia: Negotiating Public Spaces (Paul van der Haak (ed.); 8th ed.). Amsterdam University Press.

El-Rumi, U., \& Muhith, A. (2020). The Young Kyai (Lora) and Transformation of the 
Pesantren in Madura. Islam Realitas: Journal of Islamic and Social Studies, 6(2), 119136.

Elinor Ostrom \& T.K. Ahn. (2009). The Meaning of Social Capital and Its Link to Collective Action. In Gert Tinggaard Svendsen \& G. L. H. Svendsen (Eds.), Handbook of Social Capital: The Troika of Sociology, Political Science and Economics (p. 19). Edward Elgar Publishing.

Erniati. (2017). Reform of The System of Education in Pesantren. Hunafa: Jurnal Studia Islamika, 14(1), 37-58.

Etzioni-Halevy, E., \& Etzioni, A. (1974). Social Change: Sources, Patterns, and Sequences (Eva Etzioni-Halevy \& A. Etzioni (eds.)). Basic Books.

Fauzi, M. L. (2012). Traditional Islam in Javanese Society: The Roles of Kyai and Pesantren in Preserving Islamic Tradition and Negotiating Modernity. Journal of Indonesian Islam, $06(01), 125-144$.

Foas, H., \& Knobl, W. (2011). Between Structuralism and Theory of Practice: The Cultural Sociology of Pierre Bourdieu. In S. Susen \& B. S. Turner (Eds.), The Legacy of Pierre Bourdieu: Critical Essays (p. 18). Anthem Press.

Futaqi, S. (2020). Modal Sosial-Multikultural Pesantren dalam Membangun Harmoni Sosial Umat Beragama. Al- Thariqah: Jurnal Pendidikan Agama Islam, 5(2), 64-78.

George Ritzer. (2011). Sociological Theory. McGraw-Hill.

Gillian Ruch. (2010). The Contemporary Context of Relationship-Based Practice. In Relationship-Based Practice Social Work: Getting to the Heart of Practice (p. 23). Jessica Kingley Publishers.

Greg Barton. (2002). Abdurrahman Wahid: Muslim Democrat, Indonesian President. University of New South Wales Press.

Hooghe, M., \& Stolle, D. (2003). Introduction: Generating Social Capital. In M. Hooghe \& D. Stolle (Eds.), Generating Social Capital: Civil Society and Institutions in Comparative Perspective (p. 2). Palgrave Macmillan.

Hoon, C. Y. (2017). Putting Religion into Multiculturalism: Conceptualising Religious Multiculturalism in Indonesia. Asian Studies Review, 41(3), 476-493. http://doi.org/10.1080/10357823.2017.1334761

Huysman, M., \& Wulf, V. (2004). Social Capital and Information Technology: Current Debats and Research. In Social Capital and Information Technology (p. 1). The MIT Press.

James S. Coleman. (2011). Dasar-Dasar Teori Sosial (I. Mutaqien (ed.)). Nusa Media.

John Field. (2008a). Social Capital. Routledge.

John Field. (2008b). Social Capital. Routledge. 
John Field. (2008c). Social Capital. Routledge.

Julia Hauberer. (2011). Social Capital Theory: Towards a Methodological Foundation (1st ed.). Spinger Fachmedien.

Kenneth D. Benne. (2008). The Current State of Planned Changing in Persons, Groups, Communities, and Societies. In The Planning of Change (p. 79). Holt, Rinehart and Winston.

Kenneth Newton. (1999). Social Capital and Democracy in Modern Europe. In Jan Van Dept (Ed.), Social Capital and European Democracy (p. 8). Routledge.

Kutsiyah, F. (2020). Social Capital and Its Transformations in Sidogiri Islamic Boarding School. Karsa: Journal of Social and Islamic Culture, 28(1), 57-94.

Lindsay Paterson. (2000). Civil Society and Democratic Renewal. In Social Capital: Critical Perspectives (p. 69). Oxford University Press.

Lukens-Bull, R. (2019). Pesantren, Madrasa and the Future of Islamic Education in Indonesia. Kawalu: Journal of Local Culture, 6(1), 29-48.

M. Falikul Isbah. (2020). Pesantren in the Chaging Indonesian Context: History and Current Developments. Qudus International Journal of Islamic Studies (QIJIS), 8(1), 65-106. https://doi.org/10.21043/qijis.v8i1.5629

Marc Hooghe \& Dietlind Stolle. (2003). Introduction: Generating Social Capital. In Marc Hooghe \& Dietlind Stolle (Ed.), Generating Social Capital: Civil Society and Institutions in Comparative Perspective (p. 2). Palgrave Macmillan.

Martin Van Bruinessen. (1999). NU: Tradisi, Relasi-Relasi Kuasa, Pencarian Wacana Baru (Farid Wajidi (ed.)). LKiS.

Mary Holmes. (2010). Social Theory of the Body. In Anthony Elliott (Ed.), The Routledge Companion to Social Theory (p. 111). Routledge.

Marzuki, Miftahuddin, \& Murdiono, M. (2020). Multicultural Education in Salaf Pesantren and Prevention of Religious Radicalism in Indonesia. Cakrawala Pendidikan, 39(1), 1225 .

Nan Lin. (2001). The Position Generator: Measurement Techniques for Investigation of Social Capital. In Nan Lin (Ed.), Social Capital: Theory and Research (1st ed., p. 57). Aldine de Gruyter.

Nan Lin. (2008). A Network Theory of Social Capital. In Dario Castiglione (Ed.), Handbook of Social Capital (p. 51). Oxford University Press.

Nicos Mouzelis. (2005). Sociological Theory: What Went Wrong? (Diagnosis and Remedies). Routledge.

Pierre Bourdieu. (1986). The Forms of Social Capital. In John G. Richardson (Ed.), 
Handbook of Theory and Research for the Sociology of Education (p. 257). Greenwood Press.

Qomar, M. (2012). Fajar Baru Islam Indonesia?: Kajian Komprehensif atas Arah Sejarah dan Dinamika Intelektual Islam Nusantara. Mizan.

Raihani. (2012). Report on Multicultural Education in Pesantren. Compare: A Journal of Comparative and International Education, 42(4), 585-605.

Richard T. Schaefer. (2018). Sociology: A Brief Introduction. McGraw-Hill.

Ritzer, G. (2001). Explorations in Social Theory: From Metatheorizing to Rationalization. SAGE Publications.

Ritzer, G., \& Goodman, D. J. (2011). Teori Sosiologi Modern (Alimandan (ed.)). Prenadamedia Group.

Robert D. Putnam. (1993). Making Democracy Work: Civic Traditions in Modern Italy. Princeton University Press.

Robert D. Putnam. (2000). Bowling Alone: The Collapse and Revival of American Community. Simon \& Schuster.

Robert H. Lauer. (1993a). Perspektif tentang Perubahan Sosial. Rineka Cipta.

Robert H. Lauer. (1993b). Perspektif Tentang Perubahan Sosial (Alimandan (ed.)). Rineka Cipta.

Robert W. Hefner. (2009). The Politics and Cultures of Islamic Education in Southeast Asia: Introduction. In Robert W. Hefner (Ed.), Making Modern Muslims: The Politics of Islamic Education in Southeast Asia (p.5). University of Hawai'i Press.

Saefudin. (2021). The Shift in the Tradition of Islamic Education in Indonesia from the 19th Century to the Early 21st Century. Ibda': Jurnal Kajian Islam Dan Budaya, 19(1), 1-23. https://doi.org/https://doi.org/10.24090/ibda.v19i1.4391

Saeful Anam. (2019). The Moral Education nd Internalization of Humanitarian Values in Pesantren: A Case Study from Indonesia. Journal of the Education of Gifted Young Scientists, 7(4), 815-834.

Solichin, M. M. (2018). Interrelation Kiai Authorities, Curriculum and Learning Culture in Pesantren Indonesia. TARBIYA: Journal of Education in Muslim Society, 5(1), 86-100.

Suradi, A. (2018). Transformation Of Pesantren Traditions In Face The Globalization Era. Nadwa, 12(1), 27-38.

Tafsir, A., \& Aziz, A. (2019). The Concept of Jihad in Pondok Pesantren: Research in Nurussalam Islamic Boarding School Ciamis-West-Java, Indonesia. Religious Studies: An International Journal, 7(1), 37-52. 
Thoyib, M. (2018). Charismatic Leader on Developing Visionary Pesantren Bidayatul Hidayah in East Java: Profile and Strategy of Dr. KH. Ahmad Musthofa Kamal's Leadership. Jurnal Pendidikan Islam, 7(1), 79-99.

Turner, B. S. (2006). The Cambridge Dictionary of Sociology (B. S. Turner (ed.)). Cambridge University Press.

Ubaedullah, D., Akbar, M., \& Mukhtar, M. (2019). Service Quality of Pesantren and Its Impact on the Santri Loyalty. International Journal for Educational and Vocational Studies, 1(3), 254-260.

Umar, N. (2014). Rethinking Pesantren. PT. Elex Media Komputindo.

Umi Zulfa. (2018). Empowering Pesantren : A Study of Al-Ghazali's Thoughts on Islamic Education. Walisongo: Jurnal Penelitian Sosial Keagamaan, 26(1), 225-251.

Widayati, S. (2020). Pesantren and Social Empowerment: A Critical Analysis On Pesantren Al-Imdad Yogyakarta And Pesantren Maslakul Huda Central Java. Analisa: Journal of Social Science and Religion, 5(01), 51-79. 